\title{
Percutaneous Treatment of Meckel Cave Arachnoid Cyst: Case Report, Surgical Strategy and Literature Review
}

\section{Tratamento percutâneo de cisto aracnóide do cavum de Meckel: Relato de caso, estratégia cirúrgica e revisão da literatura}

\author{
Jose Augusto Malheiros Filho ${ }^{1}$ Antonio Gilson Prates Junior ${ }^{10} \quad$ Emmanuel Oliveira Vasconcelos e Sá10 \\ Luiza Cançado Guerra D’Assumpção ${ }^{10}$ Lucas Rodrigues de Souza1이 \\ ${ }^{1}$ Neurosurgery Service, Hospital das Clinicas, Universidade Federal de \\ Minas Gerais, Belo Horizonte, MG, Brazil \\ Address for correspondence Antonio Gilson Prates Junior, MD, \\ Hospital das Clinicas da Universidade Federal de Minas Gerais, Belo \\ Arq Bras Neurocir 2020;39(1):22-26. \\ Horizonte, MG, 31270-901, Brazil (e-mail: antonio.ufop@gmail.com).
}

\section{Abstract \\ Keywords \\ - Meckel cave \\ - arachnoid cyst \\ - petrous apex cephaloceles \\ - trigeminal neuralgia \\ - percutaneous treatment}

\section{Resumo}

Arachnoid cysts are benign intracranial lesions. They are usually located in the middle fossa, but can be found in other locations. We present a case of symptomatic Meckel cave (MC) arachnoid cyst - a very rare location - and a treatment strategy not elsewhere described before for this condition. A 54-year-old female with trigeminal neuralgia with previous history of radiofrequency rhizotomy treatment 6 years before admission had been experiencing pain recurrence with progression, which required successive increases in carbamazepine dosage. Magnetic Resonance Imaging (MRI) showed dilatation of the right MC with extension to the petrous apex. The lesion was compatible with arachnoid cyst, and due to the worsening of the clinical condition, surgical treatment was chosen. Percutaneous puncture of the cyst through the foramen ovale with injection of intracystic fibrin sealant was performed. The patient woke up from anesthesia with pain improvement and was discharged asymptomatic the next day. After 12 months of follow-up, she remained pain-free. In the literature review, we found only eight cases reported as MC arachnoid cyst. These are likely to progress and become symptomatic owing to their communication with the subarachnoid space and a unidirectional valve mechanism. Pain improvement with this technique is probably secondary to the interruption of these mechanisms.

Os cistos aracnoides são lesões intracranianas benignas. Geralmente estão localizados na fossa média, mas podem ser encontrados em outros locais. Apresentamos um caso de cisto aracnoide sintomático no cavum de Meckel (CM) - localização muito rara - e uma estratégia de tratamento nunca antes descrita para esta condição. Uma mulher de 54 anos com neuralgia do trigêmeo e histórico de tratamento com rizotomia por received

October 1, 2019

accepted

November 8, 2019
DOI https://doi.org/

10.1055/s-0039-3402492. ISSN 0103-5355.
Copyright (e) 2020 by Thieme Revinter

Publicações Ltda, Rio de Janeiro, Brazil
License terms

(c) $(1) \$$ 
Palavras-chave

- cavum de Meckel

- cisto aracnoide

- cefalocele do ápice petroso

- neuralgia do trigêmeo

- tratamento percutâneo radiofrequência 6 anos antes da admissão apresentava recorrência da dor com progressão, exigindo aumentos sucessivos na dosagem de carbamazepina. Ressonância magnética mostrou dilatação do $\mathrm{CM}$ à direita com extensão ao ápice petroso. $\mathrm{A}$ lesão era compatível com cisto aracnoide e, devido ao agravamento do quadro clínico, optou-se por tratamento cirúrgico. Foi realizada punção percutânea do cisto através do forame oval com injeção de selante de fibrina intracístico. A paciente acordou da anestesia com melhora da dor e recebeu alta assintomática no dia seguinte. Após 12 meses de acompanhamento, a paciente permaneceu sem dor. Na revisão da literatura, encontramos apenas oito casos relatados como cisto aracnoide do CM. É provável que estes progridam e se tornem sintomáticos devido à sua comunicação com o espaço subaracnóideo e a um mecanismo de válvula unidirecional. A melhora da dor com essa técnica é provavelmente secundária à interrupção desse mecanismo.

\section{Introduction}

Arachnoid cysts are benign intracranial lesions that account for $1 \%$ of nontraumatic intracranial lesions. ${ }^{1,2}$ They are usually located in the middle fossa, but can be found in other locations such as the suprasellar, the posterior fossa, the interhemispheric, the quadrigeminal cistern and the cerebral convexity. They are usually asymptomatic lesions, but may become symptomatic depending on location and size. ${ }^{3}$ There are several treatment options, including endoscopic or microsurgical fenestration, microsurgical excision and cyst shunt. We present a case of symptomatic arachnoid cyst in a very rare location that was treated by a strategy not described elsewhere.

\section{Case Report and Surgical Strategy}

A 54-year-old female was admitted in our service with trigeminal neuralgia in the territories of the ophthalmic and maxillary trigeminal branches. She had a history of radiofrequency rhizotomy treatment 6 years before, and at that time, the patient presented improvement and good pain maintenance control with carbamazepine $400 \mathrm{mg}$ a day. Ten months before seeking assistance, the patient recurred and experienced pain progression, which required successive increases in carbamazepine dosage up to $900 \mathrm{mg}$ a day dose to which she presented adverse reactions. Due to recurrence and worsening of the clinical condition, propae- deutic were requested. The magnetic resonance imaging (MRI) showed dilatation of the right Meckel cave (MC) with extension to the petrous apex. The lesion presented as hyperintense on T2-weighted imaging, hypointense on T1weighted imaging (-Figure 1); suppression of the signal in the T2-weighted fluid-attenuated inversion recovery and absence of diffusion restriction on diffusion weighted imaging - description compatible with arachnoid cyst. There were no neurovascular conflicts or other lesions associated with the trigeminal nerve topography. Owing to daily episodes of excruciating pain and intolerance to drug treatment, surgical treatment was chosen.

Percutaneous puncture of the cyst through the foramen ovale with injection of intracystic fibrin sealant was performed. The patient did not tolerate the sedation, so the procedure took place under general anesthesia. A 20-Gauge spinal needle was inserted through the ascending extraoral transoval route guided by lateral incidence fluoroscopy. ${ }^{4}$ The introduction pathway started $3 \mathrm{~cm}$ lateral to the labial commissure and ascended until the intersection point between the coronal plane $3 \mathrm{~cm}$ anterior to the tragus and the sagittal plane of the pupil. After touching the skull base, the needle was directed under fluoroscopy to the foramen ovale, using as reference point the clivus intersection with the petrous pyramid. After entrance, the position of the needle was confirmed by fluoroscopy (-Figure 2A) and through
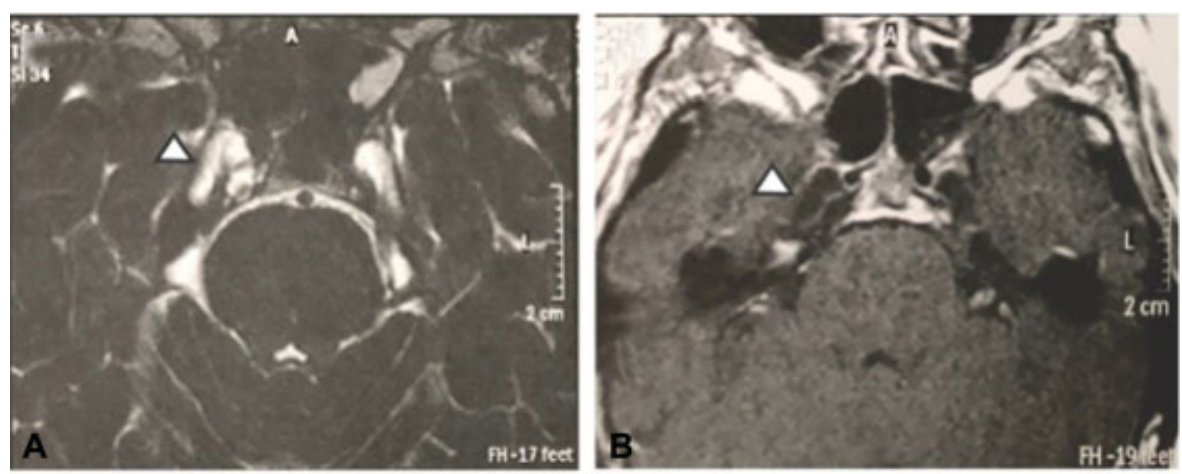

Fig. 1 Meckel cave (MC) arachnoid cyst on magnetic resonance imaging (MRI). (A) T2-weighted MRI image showing right MC dilatation with cerebrospinal sign (arrow). (B) T1- weighted MRI image showing right MC dilatation (arrow). 

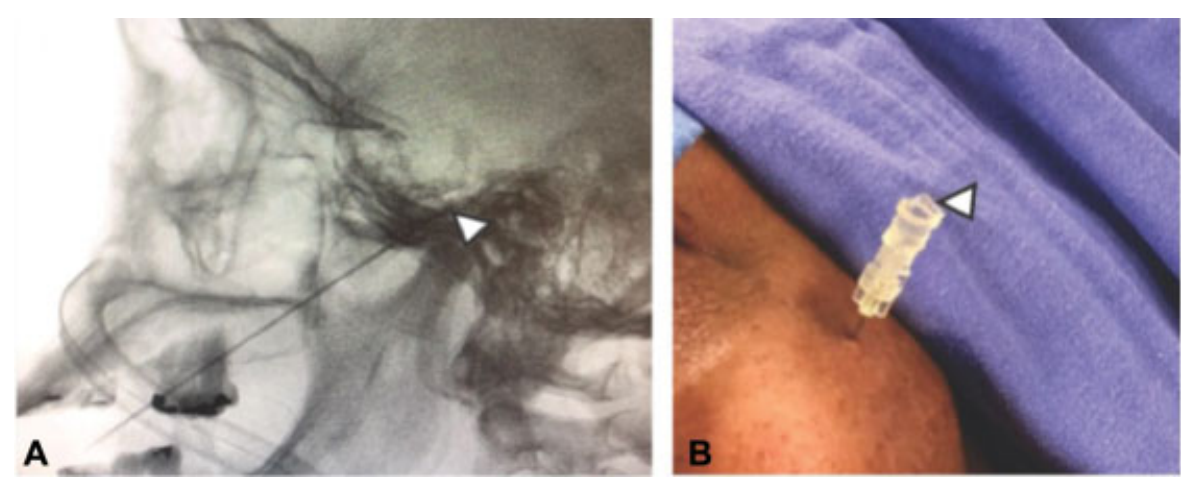

Fig. 2 Surgical technique. (A) Fluoroscopy-guided foramen ovale puncture. Note the tip of the needle in the intracranial compartment (arrow). (B) Puncture point $3 \mathrm{~cm}$ lateral to lip rhyme. Note the leakage of cerebrospinal fluid through the needle (arrow).

cerebrospinal fluid (CSF) leakage through its lumen (-Figure 2B). On account of active CSF drainage after the puncture, we chose not to inject contrast. Then $2 \mathrm{~mL}$ of Tissucol was injected and the needle was removed. The patient woke up from anesthesia with pain improvement and was discharged asymptomatic the next day. The MRI performed on the first postoperative day revealed reduction of the cyst dimensions and partial filling of the cyst by T2weighted hypointense material extending through the cisternal segment of the trigeminal nerve (-Figure 3 ). After 12 months of follow-up, tapering of carbamazepine dose was achieved and the patient remained pain-free using only $400 \mathrm{mg}$ a day.

\section{Discussion}

Arachnoid cysts are collections of intracranial CSF surrounded by arachnoid layers. They can be primary

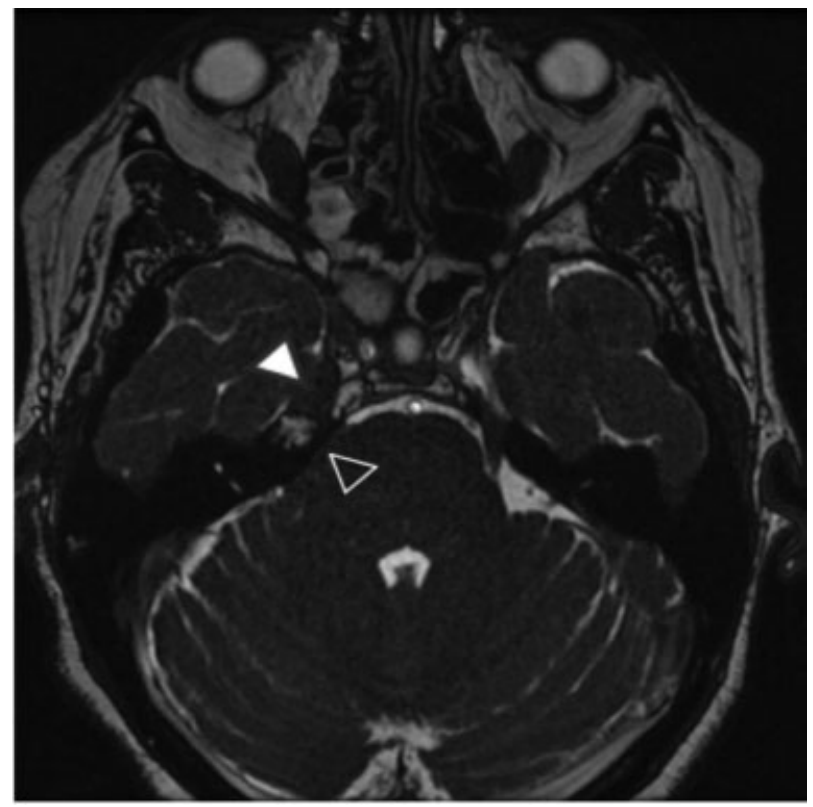

Fig. 3 Postoperative T2 -weighted magnetic resonance imaging showing partial filling of the cyst by with hypointense material (white arrow) extending through the cisternal segment of the trigeminal nerve (black arrow). or secondary. The primaries are benign malformations originated from arachnoid division during development resulting in anomalous CSF collections. The secondary ones are less common and are associated with neoplasms, infections, bleeding, trauma or surgery. ${ }^{2,3}$ Depending on their location and size, arachnoid cysts may become symptomatic.

In a literature review, we found only eight cases reported as MC arachnoid cyst ( - Table 1)..$^{2,5-11}$ The average age of the patients was 41 years old - with a range from 1 to 58 years old - and there was a female predominance ( 5 out of 8 ). The most affected side was the right side (five out of eight). In all but one case, there was trigeminal neuralgia in 1 or more branches territories, associated or not with symptoms of other cranial pairs, such as diplopia, vertigo, and hearing loss. The patient in whom no neuralgia was reported was a 1.5year-old child with exophthalmos and diplopia. ${ }^{10}$ In only three cases the lesion was referred to as restricted to the MC, and in one of these, no MRI was performed and the lesion was not described in details in the article. ${ }^{10}$ We can conclude that MC cysts tend to extend to adjacent regions, especially to the petrous apex - as occurred in the case reported in the present paper.

Of the reported cases, two were treated with drugs alone; five were treated surgically and one had spontaneous resolution. Of the five surgically treated patients, four underwent craniotomy treatment and only one underwent percutaneous treatment with cyst aspiration through the foramen ovale puncture. ${ }^{2}$ In this patient, the control MRI presented cyst persistence and the author attributed the improvement to possible rhizotomy by injected contrast or needle injury. ${ }^{2}$ Moreover, these data show the importance of preoperative differential diagnosis by MRI of lesions in the MC because in all patients undergoing craniotomy, the diagnosis of arachnoid cyst was made intraoperatively, excluding the possibility of less invasive treatment. $5,6,10,11$

There are reports of petrous apex cephaloceles. These are uncommon lesions, rarely described in the literature and sometimes radiologically indistinguishable from arachnoid cysts of the MC. They are considered by some authors to be the same entity ${ }^{2,8}$. Defined as cystic lesions with a cerebrospinal fluid-like sign at the petrous apex that protrude through the posterolateral wall of the MC, they can be 
Table 1 Cases Reported in the Literature

\begin{tabular}{|c|c|c|c|c|}
\hline Author & $\begin{array}{l}\text { Age } \\
\text { (years old), } \\
\text { gender }\end{array}$ & Symptoms & Location, side & Treatment \\
\hline Wörner et al & $44, \mathrm{M}$ & $\begin{array}{l}\text { Dysesthesia in V3, vertigo } \\
\text { and diplopia }\end{array}$ & Meckel cave, CPA, R & Open resection \\
\hline Batra et al ${ }^{6}$ & $55, F$ & Pain and paresthesia in V3 & $\begin{array}{l}\text { Petrous apex, Meckel's } \\
\text { cave, } \mathrm{R}\end{array}$ & Open fenestration \\
\hline Bigder et $a l^{2}$ & $57, \mathrm{~F}$ & $\begin{array}{l}\text { Pain in V2, temporal mus- } \\
\text { cle atrophy and hemifacial } \\
\text { paresthesia }\end{array}$ & Meckel cave, L & Percutaneous drainage \\
\hline Fois et al ${ }^{7}$ & $42, F$ & $\begin{array}{l}\text { Sensorineural hearing loss } \\
\text { and neuralgia }\end{array}$ & $\begin{array}{l}\text { Meckel cave, petrous } \\
\text { apex, B }\end{array}$ & Medication \\
\hline Jacob et $a l^{8}$ & $32, \mathrm{~F}$ & Diplopia and pain in $\mathrm{V} 1$ & Meckel cave, $\mathrm{R}$ & Spontaneous resolution \\
\hline Grasso et al ${ }^{9}$ & $40, M$ & Neuralgia in V2-V3 & $\begin{array}{l}\text { Meckel cave, middle } \\
\text { fossa and greater wing of } \\
\text { sphenoid, } L\end{array}$ & Medication \\
\hline Beck et al ${ }^{10}$ & $1, M$ & Exophthalmia and diplopia & Meckel cave, $R$ & Open resection \\
\hline Jelsma et al ${ }^{11}$ & $58, F$ & $\begin{array}{l}\text { Neuralgia and hemifacial } \\
\text { hypoesthesia }\end{array}$ & $\begin{array}{l}\text { Meckel cave, petrous } \\
\text { apex, } R\end{array}$ & Open fenestration \\
\hline
\end{tabular}

Abbreviations: B, bilateral; CPA, cerebellopontine angle; F, female; L, left; M, male; R, right; V1, ophthalmic trigeminal branch; V2, maxillary trigeminal branch; V3, mandibular trigeminal branch.

composed of dura mater and arachnoid or just arachnoid being described as meningoceles and arachnoid cysts. ${ }^{12-15}$ However, dilatation may be restricted to the petrous apex without dilatation of the MC and they are usually not associated with trigeminal neuralgia, but with sixth cranial nerve neuropathy and otological symptoms. ${ }^{8,12}$ Possibly, they are part of the same spectrum of disease of the arachnoid cyst in the MC differing only in presentation and progression.

Meckel cave arachnoid cysts are likely to progress and become symptomatic due to their communication with the subarachnoid space and a unidirectional valve mechanism that only allows CSF entry. This communication between the cyst and the CSF system may allow the transmission of pulsations to the nerve and cyst enlargement causing trigeminal neuralgia by a mechanism similar to neurovascular compression. ${ }^{9}$

We describe a noninvasive, effective and safe technique for the treatment of Meckel cave arachnoid cysts. We did not find in the literature a description of the same strategy. The improvement mechanism with this technique is probably the interruption of the communication between the cyst and the cerebrospinal fluid system, which prevents the transmission of pulsations to the nerve and enlargement of the cyst.

\section{Conclusion}

Meckel cave arachnoid cysts are rare lesions in which preoperative differential diagnosis is very important for proper surgical planning and for individualized treatment with less morbidity. Filling the cyst with fibrin sealant by percutaneous puncture was effective for symptomatic control of the patient with minimal associated morbidity. We consider that this technique should be considered for surgical treatment of this lesion.

\section{Conflict of Interests}

The authors have no conflict of interests to declare.

\section{References}

1 Vernooij MW, Ikram MA, Tanghe HL, et al. Incidental findings on brain MRI in the general population. N Engl J Med 2007;357(18): 1821-1828

2 Bigder MG, Helmi A, Kaufmann AM. Trigeminal neuropathy associated with an enlarging arachnoid cyst in Meckel's cave: case report, management strategy and review of the literature. Acta Neurochir (Wien) 2017;159(12):2309-2312

3 Mustansir F, Bashir S, Darbar A. Management of Arachnoid Cysts: A Comprehensive Review. Cureus 2018;10(04):e2458

4 Gusmão SNS, de Oliveira MM, Arantes AA Junior. Rizotomia trigeminal por radiofrequência para tratamento da neuralgia do trigêmeo - resultados e modificação técnica. Arq Neuropsiquiatr 2003;61(2-B):434-440

5 Wörner BA, Noll M, Rahim T, Fink U, Oeckler R. Recurrent arachnoid cyst of Meckel's cave mimicking a brain stem ischaemia. Report of a rare case. Zentralbl Neurochir 2003;64(02): 76-79

6 Batra A, Tripathi RP, Singh AK, Tatke M. Petrous apex arachnoid cyst extending into Meckel's cave. Australas Radiol 2002;46(03): 295-298

7 Fois P, Lauda L. Bilateral Meckel's cave arachnoid cysts with extension to the petrous apex in a patient with a vestibular schwannoma. Otol Neurotol 2011;32(05):e36-e37

8 Jacob M, Gujar S, Trobe J, Gandhi D. Spontaneous resolution of a Meckel's cave arachnoid cyst causing sixth cranial nerve palsy. J Neuroophthalmol 2008;28(03):186-191

9 Grasso G, Passalacqua M, Giambartino F, Cacciola F, Caruso G, Tomasello F. Typical trigeminal neuralgia by an atypical 
compression: case report and review of the literature. Turk Neurosurg 2014;24(01):82-85

10 Beck DW, Menezes AH. Lesions in Meckel's cave: variable presentation and pathology. J Neurosurg 1987;67(05):684-689

11 Jelsma F, Ross PJ. Traumatic intracranial arachnoidal cyst involving the Gasserian ganglion. Case report. J Neurosurg 1967;26(04):439-441

12 Moore KR, Fischbein NJ, Harnsberger HR, et al. Petrous apex cephaloceles. AJNR Am J Neuroradiol 2001;22(10):1867-1871
13 Alkilic-Genauzeau I, Boukobza M, Lot G, George B, Merland JJ. CT and MRI features of arachnoid cyst of the petrous apex: report of 3 cases. J Radiol 2007;88:1179-1183

14 Alorainy IA. Petrous apex cephalocele and empty sella: is there any relation? Eur J Radiol 2007;62(03):378-384

15 Isaacson B, Coker NJ, Vrabec JT, Yoshor D, Oghalai JS. Invasive cerebrospinal fluid cysts and cephaloceles of the petrous apex. Otol Neurotol 2006;27(08):1131-1141 